\title{
Collaborative Professional Development Focused on Promoting Effective Implementation of the Next Generation Science Standards
}

\author{
Laila J. Richman ${ }^{1 *}$, Sarah Haines ${ }^{2}$, Shannon Fello ${ }^{3}$ \\ ${ }^{1}$ Department of Special Education, College of Education, Towson University, Towson, Maryland, United States of America, ${ }^{2}$ Department of Biological \\ Sciences, College of Science and Mathematics, Towson University, Towson, Maryland, United States of America, ${ }^{3}$ Department of Science, Baltimore \\ County Public Schools, Baltimore, Maryland, United States of America
}

*Corresponding Author: Irichman@towson.edu

\section{ABSTRACT}

The purpose of this study was to examine the design, implementation, and initial outcomes of a collaborative professional development program intended to prepare middle and high school educators to implement effectively the Next Generation Science Standards (NGSS) in classrooms with diverse learners. The professional development program discussed herein was designed by a university in partnership with a local school district and incorporated key principles of effective professional development associated with promoting substantial changes in teacher knowledge and practice recommended in the research literature (Darling-Hammond et al., 2009; Guskey, 2002; Reiser, 2013). Topics covered in the professional development included NGSS practices and crosscutting concepts, Universal Design for Learning, and disciplinary literacy. Results suggest that the impact of this professional development program was positive. Feedback from participants was favorable and will be shared as well.

KEY WORDS: Next Generation Science Standards; professional development; Universal Design for learning; diverse learners, literacy

\section{INTRODUCTION}

"] n collaborative working environments, teachers have the potential to create the collective capacity for initiating and sustaining ongoing improvement in their professional practice so each student they serve can receive the highest quality of education possible" (Pugach and Johnson, 2002, p. 6). Given the increasing requirements and responsibilities faced by teachers, particularly with the implementation in the United States of the Common Core Curriculum, collaboration is essential. It is no longer possible for teachers to meet the needs of students in isolation, but rather, teachers must collaborate to help all students learn successfully.

\section{LITERATURE REVIEW}

The National Science Education Standards define enquiry as: The diverse ways in which scientists study the natural world and propose explanations based on the evidence derived from their work. Scientific enquiry also refers to the activities through which students develop knowledge and understanding of scientific ideas, as well as an understanding of how scientists study the natural world (National Research Council, 1996, p. 23).

The Science and Engineering Practices of the Next Generation Science Standards (NGSS) give students opportunities to develop the abilities necessary to do scientific inquiry and to understand the nature of the scientific enquiry. It has been well established in the science education literature that enquirybased teaching promotes better learning and retention of content (Anderson, 2002; Davis and Krajcik, 2005; Furtak et al., 2008; Hickey et al., 2003). The use of enquiry-based instruction and focus on enquiry during planned professional development strongly supports constructivist learning theory (Jonassen, 1994; Kim, 2005; Meyer, 2009). Many current reform efforts are associated with the theory of constructivism, and following this epistemology can be useful to the practicing teacher (Lorsbach and Tobin, 2008).

Science educators argue that writing can promote students' understanding of science concepts (Prain and Hand, 1996). Studies of writing during science indicate that writing can improve their recall of science facts and understanding of scientific concepts (Gunel et al., 2007; Mason and Boscolo, 2000) and promote their understanding of scientific questions, claims, and evidence (Wallace et al., 2004). This work demonstrates that writing about science in everyday language, re-wording scientific ideas for different audiences (peers, parents, and younger children), and writing in a variety of forms (letters, journals, and explanations) enhances science learning.

Graham and Hebert (2011) posit that writing can not only increase a student's understanding of the content being 
written about but it can also increase the student's reading comprehension as well. In this meta-analysis, they also found that increasing writing instruction and writing opportunities also increased reading comprehension, particularly for those who struggle with reading. Researchers who study reading in science have begun to advocate for a disciplinary stance toward teaching students to read scientific texts (Moje, 2008; Shanahan and Shanahan, 2008). A recent study by Shanahan et al. (2012) determined that mathematicians, historians, and chemists read texts differently. Chemists differed from those in other disciplines in the strategies they used to make sense of scientific texts. This means that science teachers must teach discipline-specific, rather than general purpose, reading comprehension strategies if they hope to help their students understand the content they are reading.

Universal Design for Learning (UDL) "provides a framework for curriculum design, instructional processes, and assessment that gives all students equal opportunities to learn and to demonstrate what they have learned" (Statewide Task Force, 2011, p. 1). It is a way of teaching that builds on existing initiatives such as reciprocal teaching, cooperative learning, and differentiation, by utilizing current brain research to enhance instruction for individual learners. UDL is referenced in numerous state and federal policies that guide education and is now required in the state of Maryland. The Higher Education Opportunity Act (HEOA) (United States Department of Education, 2008) validates UDL as a scientific framework for guiding educational practice. UDL has been described as the "intersection where all of our best initiatives - integrated units, multi-sensory teaching, multiple intelligences, differentiated instruction, use of computers in schools, performance-based assessment, and others - come together" (Rose et al., 2002, p. 7).

\section{METHODOLOGY}

\section{Description of the Professional Development Program}

This study's professional development program was funded through a grant from the Maryland Higher Education Commission and the U.S. Department of Education under the auspices of the Teacher and Principal Training and Recruiting Fund Partnership Grant Program. This program, administered by an institution of higher education, focused directly on student learning and content, was aligned to current school and district initiatives, and supported strong collaborative relationships among teachers. The project provides $91 \mathrm{~h}$ of professional development activities that focus on increasing the teachers' content and pedagogical knowledge related to effectively implementing the NGSS, with specific emphasis on the Science and Engineering principles and crosscutting concepts. This is accomplished through a comprehensive professional learning sequence beginning with an understanding of the rationale and major shifts of the NGSS overall and then focusing on the specific principles and concepts. In addition, teachers received training on the use of UDL, integrating the Common Core ELA(English Language Arts) literacy standards in science, and serving as teacher leaders. The goals of the professional development program were that participating teachers would:

- Gain the content knowledge and understanding required to implement effectively the NGSS;

- Develop the pedagogical knowledge required to implement effectively the NGSS;

- Improve their knowledge and understanding of how to implement effectively the Common Core ELA literacy standards into science; and,

- Apply the principles of UDL in their lesson planning and teaching.

After an initial orientation meeting, participants completed a series of workshops in spring 2015 (45 h). During these workshops, teachers spent time interacting with and developing a deeper understanding of each of the NGSS practices and crosscutting concepts. Each session focused on one NGSS practice and one crosscutting concept. Participants evaluated the purpose and the theory behind each practice and crosscutting concept and analyzed the increasing complexity of each practice and crosscutting concept across the different grade bands. Participants engaged in multiple content-related tasks and activities that modeled the implementation of the practice and crosscutting concept in the middle school classroom. Throughout each session, participants were continuously asked to recognize the interrelatedness among the content, the practices, and the crosscutting concepts. At the conclusion of each session, participants applied their understanding of the practice and crosscutting concept to their specific grade-level curricula by either developing or modifying a lesson they could teach in their classrooms.

In addition, instructional content coaches demonstrated strategies that could be used for promoting reading and writing in science. Teachers then examined effective ways of promoting disciplinary reading and writing aligned to the NGSS and integrated these strategies into their curricula for the fall. Participating teachers also became more comfortable in the use of UDL and had multiple opportunities to apply UDL in their lessons during the summer and fall activities.

Next, teachers attended a summer workshop ( $25 \mathrm{~h}$ ) focused on applying the NGSS Science and Engineering principles and crosscutting concepts in their curricula for the upcoming school year. During the workshop, participants were given the opportunity to work within grade-level teams to analyze the curricula that would be taught in the fall. Participants were asked to select two or three practices and crosscutting concepts on which to focus for the upcoming academic year. Participants then mapped out and developed a plan for implementation of the practices and crosscutting concepts into their identified unit of instruction. Once these tasks were accomplished, participants developed one pre-assessment and one summative assessment along with a scoring tool to be used for monitoring and measuring student growth. In the end, they were able to obtain critical feedback on their developed lesson plans from their instructional coaches and peers. 
During the fall and upcoming spring, teachers participated in follow-up activities including site-visits, focus groups, lesson studies, observations, and a final colloquium, resulting in an additional 21 follow-up h. The follow-up sessions were designed to provide additional professional development on pedagogy and best practices that support the NGSS initiative and overall student success in science. Topics for the sessions included brain-based learning, growth mindset, alternative assessment, and teachers as leaders. Participants showcased student successes as well as their own personal and professional experiences of professional development during the colloquium.

\section{Participants}

While twenty-five teachers completed the pre-assessments, three teachers decided to withdraw from the project before the first session. Because the pre-assessments were anonymous, their data were included in the study. Ultimately, twenty-two teachers from 14 different schools participated in the project. They taught a range of grade levels with one teaching in $5^{\text {th }}$ grade, 15 teaching $6^{\text {th }}-8^{\text {th }}$ grade, and six teaching $9^{\text {th }}-12^{\text {th }}$ grade. All twentytwo teachers had certification in science and four had an additional certification in special education. In addition, ten teachers held Advanced Professional Certifications, two held their administration certification, two held conditional or provisional certification, one was a highly qualified paraeducator (but had science certification in another state), and four were considered new teachers.

\section{Evaluation}

Guskey's (2002) model suggests that professional development results in sustained change based on teachers' witnessing evidence of successful implementation of practices in the classroom. Only after teachers observe evidence of success are, they likely to change their beliefs and attitudes about newly learned practices. This contrasts with traditional models which assume professional development produces a change in teachers' beliefs and attitudes, which then increase the likelihood teachers will try out new learning in the classroom. In alignment with Guskey, overall teacher attitudes and beliefs were assessed after teachers had time to implement learning from their participation in the spring and summer programs. In addition, evidence of teacher learning and changes in practice were collected in the classroom through classroom observation and lesson studies during the year.

Two other elements of the professional development experience (practice during the school year and coaching) are consistent with Guskey's assertions that teacher change is slow and gradual and requires ongoing support. The evaluation plan collected data both in the short-term (following each workshop and follow-up meeting) and long-term (at the end of the project) to allow teacher change to unfold gradually and to provide support over time.

The plan considered multiple knowledge and skill areas, the longitudinal framework over which the professional development unfolded, and uses a mix of both quantitative and qualitative methodologies to evaluate the needs for, and impact of, this PD program. Data sources used to evaluate the effectiveness of the PD, and overall changes in teacher knowledge and practice included session feedback, site-based observations, lesson plan materials, and surveys.

\section{FINDINGS}

\section{Professional Development Sessions}

At the first spring workshop, a pre-assessment of participants' knowledge of the NGSS Science and Engineering Practices was collected. The assessment asked participants to identify and describe the eight practices. At the final spring workshop, a post-assessment was administered. Knowledge about each of the NGSS Science and Engineering Practices increased from their baseline levels, as shown in Table 1 .

A pre-assessment of participants' knowledge of the NGSS Crosscutting Concepts was also collected at the first workshop. The assessment asked participants to identify and describe the seven crosscutting concepts. At the final Spring Workshop, a post-assessment was administered. Knowledge about each of the NGSS Crosscutting Concepts increased from baseline levels, as shown in Table 2.

At the conclusion of each professional development session, participants were asked to rate how often they would be able to use what they had learned in their teaching. Overall, $54 \%$ of participants said they would use what they had learned "very often," $37 \%$ said they would use it "often," $8 \%$ said they would use is "sometimes," and $2 \%$ indicated they would "rarely" use

\begin{tabular}{lccccc}
\hline Table 1: Pre- and post-assessment data for NGSS Science & and Engineering Practices & \\
\hline NGSS Science and Engineering Practices & Pre (25) & Percentage & Post (21) & Percentage & Increase over baseline (\%) \\
\hline Asking questions and defining problems & 6 & 24 & 18 & 86 & 62 \\
Developing and using models & 11 & 44 & 19 & 90 & 43 \\
Planning and carrying out investigations & 7 & 25 & 13 & 62 & 37 \\
Analyzing and interpreting data & 8 & 32 & 17 & 81 & 71 \\
Using mathematics and computational thinking & 5 & 20 & 15 & 43 & 51 \\
Developing expectations and designing solutions & 3 & 12 & 9 & 71 & 31 \\
Engaging in argument from evidence & 5 & 20 & 15 & 71 & 63 \\
Obtaining, evaluating, and communicating information & 2 & 8 & & & 75 \\
\hline
\end{tabular}


that they had learned. When asked what they found beneficial about the sessions, some responses included:

- "Designing labs"

- "Observing and making decisions about how to control the outcome"

- "Collaboration - I am learning so much just from talking and working with other teachers"

- "Time to contemplate teaching of crosscutting concepts with other teachers"

- "Discussing crosscutting concepts three and four - it helped to hear others' thoughts on how to apply it in the class"

- "Learning there is a difference between writing to learn science and learning to write science"

- "Ideas for teaching arguments"

- "UDL information"

- "Practice teaching lab like a student would practice generating questions".

For the summer workshop, the overall feedback was positive (Table 3). A sample of the qualitative feedback from the summer sessions identifies what teachers found most helpful:

- "Becoming familiar with the concepts and practices of NGSS, the Common Core Reading and Writing expectations, and UDL practices the reading and writing in science strategies, the guest speakers ***The ability to work with teachers from other schools and collaborate together"
- "Extremely beneficial in giving me the opportunity to learn new strategies to improve student learning. It has also given me the opportunity to work with other teachers to make quality learning experiences for my students. Having designated time to work and improve on what we will be teaching in the fall has been so beneficial to me!"

- "Time to work with group members on modifying lessons to meet NGSS and Common Core Reading and Writing Standards were very beneficial. It was a good use of time to collaborate with other teachers from other schools as well. As a special educator, it was helpful for me and the group to take time to really think about all the students and what they will need to be successful."

\section{Site-based Observations}

Participants worked in groups to develop unit and lesson plans to implement the NGSS effectively. Teachers were observed implementing these lessons in the fall and again in the spring. Data showing the percentage of participants who included the indicated NGSS Science and Engineering Practices and Crosscutting Concepts into their lessons appear, as shown in Tables 4 and 5 .

Participants also received training on integrating the Common Core ELA literacy standards during the Spring Workshops. During the Summer Workshop, teachers were instructed and given support to integrate the Common Core ELA standards in the lessons and unit plans they were developing. Table 6

\begin{tabular}{lccccc}
\hline \multicolumn{7}{l}{ Table 2: Pre- and post-assessment data for NGSS Crosscutting Concepts } \\
\hline NGSS crosscutting concepts & Pre (25) & Percentage & Post (21) & Percentage & Increase over baseline (\%) \\
\hline Patterns & 5 & 20 & 14 & 67 & 47 \\
Cause and effect & 4 & 16 & 14 & 67 & 51 \\
Scale, proportion, and quantity & 0 & 0 & 13 & 62 & 62 \\
Energy and matter & 5 & 20 & 14 & 67 & 47 \\
Systems and system models & 4 & 16 & 13 & 62 & 46 \\
Structure and function & 0 & 0 & 12 & 57 & 57 \\
Stability and change & 1 & 4 & 12 & 57 & 53 \\
\hline
\end{tabular}

Table 3: Participant overall satisfaction with summer workshop $(n=17)$

\begin{tabular}{lcc}
\hline Question & Strongly agree & Agree \\
\hline $\begin{array}{l}\text { The content of the summer workshop constituted meaningful and important } \\
\text { science for middle and/or high school. }\end{array}$ & 8 \\
$\begin{array}{l}\text { Activities and discussions during the workshop enhanced my knowledge } \\
\text { and understanding of related content. }\end{array}$ & 11 \\
$\begin{array}{l}\text { Activities and discussions during the PD sessions I attended have positively } \\
\text { influenced my teaching of related content. }\end{array}$ & 8 \\
$\begin{array}{l}\text { The information learned from participating in this project has/will } \\
\text { positively impact the achievement of my students. }\end{array}$ & 5 \\
$\begin{array}{l}\text { Project activities and discussions were engaging. } \\
\text { Participating in the Summer Workshop has been a worthwhile and valuable } \\
\text { professional development experience for me. }\end{array}$ & 11 \\
$\begin{array}{l}\text { Item } \\
\text { Approximately, how often do you believe you have applied the information } \\
\text { learned from the PD sessions with your students? }\end{array}$ & Every day \\
\hline
\end{tabular}


illustrates the percentage of participants who included the indicated reading standards for literacy in science and technical subjects into their lesson.

In addition, Table 7 shows the percentage of participants who included the indicated writing standards for literacy in science and technical subjects into their lesson. While content coaches did not observe an overall increase in the integration of the MCCRS-ELA over time, their feedback indicated that it was in part due to the specific lesson they were observing.

\begin{tabular}{lcc}
\hline $\begin{array}{l}\text { Table 4: Percentage of classroom } \\
\text { included the NGSS practice }\end{array}$ & & \\
\hline NGSS Science and Engineering & Fall & Spring \\
Practice & $\mathbf{2 0 1 5}$ & $\mathbf{2 0 1 6}$ \\
\hline Asking questions/defining problems & 66 & 54 \\
Developing and using models & 40 & 39 \\
Planning and carrying out investigations & 20 & 31 \\
Analyzing and interpreting data & 30 & 46 \\
Using mathematics and computational & 10 & 39 \\
thinking & & \\
Constructing explanations and designing & 40 & 54 \\
solutions & & \\
Engaging in argument from evidence \\
$\begin{array}{l}\text { Obtaining, evaluating, and communicating } \\
\text { information }\end{array}$
\end{tabular}

\begin{tabular}{lcc}
\hline \multicolumn{3}{l}{ Table 5: Percentage of classroom observations that } \\
included the NGSS crosscutting concept \\
\hline NGSS crosscutting concept & Fall & Spring \\
& $\mathbf{2 0 1 5}$ & $\mathbf{2 0 1 6}$ \\
\hline Patterns & 10 & 39 \\
Cause and effect & 60 & 62 \\
Scale, proportion, and quantity & 20 & 23 \\
Systems and system models & 0 & 15 \\
Energy and matter & 20 & 31 \\
Structure and function & 10 & 15 \\
Stability and change & 0 & 15 \\
\hline
\end{tabular}

Participants worked in groups to develop unit and lesson plans to implement the NGSS and were also instructed to apply UDL principles to the lesson to increase access to the widest range of learners. Table 8 illustrates the percentage of participants who included the indicated UDL principles into their lesson. Overall, content coaches observed an increase in the application of the UDL principles in planning.

On the observation instrument as whole, participants were assigned an overall rating of "highly effective," "effective," "developing effective," or "Ineffective" on their lesson plan. The overall criteria are described below.

\section{Highly Effective}

- The lesson provides a combination of at least three or more of the NGSS Practices and Crosscutting concepts.

- The lesson shows clear evidence of the CCSS for reading in science and technical subjects (RST). The lesson provides opportunities for students to identify key ideas and details and to integrate knowledge and ideas.

- The lesson shows clear evidence of the CCSS for writing in science and technical subjects (WHST). The lesson provides at least one of the writing standards.

- The lesson incorporates UDL Principles and Guidelines to differentiated instruction to meet the needs of students. The lesson should provide at least two of the three principles in its design and implementation.

\section{Effective}

- The lesson provides at least two or more of the NGSS Practices and Crosscutting concepts.

- The lesson shows evidence of the CCSS for reading and science technical subjects (RST). The lesson may attempt to provide opportunities for identifying key ideas and details and to integrate knowledge and ideas, but refinement of these are needed.

- The lesson incorporates one of the WHST.

- The lesson begins to incorporate UDL Principles and Guidelines. At least one of the three principles is provided in the lesson design and implementation.

\section{Table 6: Percentage of classroom observations that included the reading standards}

\begin{tabular}{lcc}
\hline Reading standards for literacy in science and technical subjects (RST) & Fall 2015 & 20 \\
\hline Cite textual evidence. & 50 & Spring 2016 \\
$\begin{array}{l}\text { Determine the central ideas or conclusions of a text; provide summary of the text distinct } \\
\text { from prior knowledge or opinions. }\end{array}$ & 40 \\
$\begin{array}{l}\text { Follow precisely a multistep procedure when carrying out experiments, taking } \\
\text { measurements, or performing technical tasks. }\end{array}$ & 50 \\
$\begin{array}{l}\text { Determine the meaning of symbols, key terms, and other domain-specific words and } \\
\text { phrases as they are used in a specific scientific or technical context relevant to Grades }\end{array}$ & 23 \\
$\begin{array}{l}\text { 6-8 texts. } \\
\text { Integrate quantitative or technical information expressed in words in a text with a } \\
\text { version of the information expressed visually (e.g., in a flowchart, diagram, model, }\end{array}$ & 40 \\
graph, or table). & 31 \\
$\begin{array}{l}\text { Distinguish among facts, reasoned judgment based on research findings, and speculation } \\
\text { in a text. }\end{array}$ & 0 \\
$\begin{array}{l}\text { Compare and contrast the information gained from experiments, simulations, video or } \\
\text { multimedia sources with that gained from reading a text on the same topic. }\end{array}$ & 40 \\
\hline
\end{tabular}




\section{Table 7: Percentage of classroom observations that included the writing standards}

\section{Writing standards for literacy in science and technical subjects (WHST)}

Write arguments focused on discipline-specific content.

Write informative/explanatory texts, including the scientific procedures/experiments, or technical process. Produce clear and coherent writing in which the development, organization, and style are appropriate to task, purpose, and audience.

Develop and strengthen writing as needed by planning, revising, editing, rewriting, or trying a new approach, focusing on how well purpose and audience have been addressed.

Use technology, including the internet, to produce and publish writing and present the relationships between information and ideas clearly and efficiently.

Conduct short research projects to answer a question (including a self-generated question), drawing on several sources and generating related, focused questions that allow for multiple avenues of exploration.

Gather relevant information from multiple print and digital sources, using search terms effectively; assess the credibility and accuracy of each source, and quote or paraphrase the data and conclusions of others while avoiding plagiarism and following a standard form of citation.

Draw evidence from informational texts to support analysis, reflection, and research.

\begin{tabular}{cc} 
Fall 2015 & Spring 2016 \\
\hline 30 & 31 \\
20 & 7 \\
40 & 31 \\
0 & 8 \\
0 & 8 \\
30 & 8 \\
0 & 8 \\
& \\
& \\
& \\
&
\end{tabular}

\section{Effective Developing}

- The lesson begins to address the NGSS Practices and Crosscutting concepts. However, the practices may be unclear or illogical for the purpose of the lesson.

- The lesson shows an attempt to include RST standards. However, the lesson may need refinement in its design of providing students opportunities to identify key ideas and details and to integrate knowledge and ideas.

- The lesson incorporates one of the WHST; however, it may not be appropriate for science. Refinement of the element is required.

- The lesson begins to incorporate UDL Principles and Guidelines. At least one of the three principles is provided in the lesson design and implementation.

\section{Ineffective}

- The lesson does not contain evidence of NGSS Practices and Crosscutting concepts.

- The lesson lacks RST standards and implementation of CCSS for reading is not evident.

- WHST standards are lacking, and the implementation of CCSS for writing is not evident.

- UDL is not addressed or implemented within the lesson framework.

Overall, $85 \%$ of teachers observed in the spring were rated "highly effective" or "effective," $15 \%$ were rated "effective developing," and none received a rating of "ineffective."

\section{Surveys}

Participants completed a UDL pre-survey to evaluate their knowledge and understanding of the UDL principles. They also received professional development on the UDL principles and how to apply them to the science content in a Spring Workshop. In addition, a session on utilizing technology to support access was provided during the Summer Workshop, and examples of how UDL could be integrated into their units were also shared. Table 9 shows the teachers growth over the baseline. While their perceptions did not increase in every area, their performance in Table 8 shows they still increased their ability to apply UDL.

\begin{tabular}{|c|c|c|c|}
\hline $\begin{array}{l}\text { Universal Design for } \\
\text { Learning principle }\end{array}$ & $\begin{array}{l}\text { Fall } \\
2015\end{array}$ & $\begin{array}{c}\text { Spring } \\
2016\end{array}$ & Change \\
\hline Options for perception & 50 & 85 & +35 \\
\hline $\begin{array}{l}\text { Options for language and } \\
\text { symbols }\end{array}$ & 50 & 77 & +27 \\
\hline Options for comprehension & 20 & 85 & +65 \\
\hline Options for physical action & 50 & 54 & +4 \\
\hline $\begin{array}{l}\text { Options for expressive skills and } \\
\text { fluency }\end{array}$ & 30 & 54 & +28 \\
\hline Options for executive functions & 30 & 62 & +32 \\
\hline Options for recruiting interest & 40 & 77 & +37 \\
\hline $\begin{array}{l}\text { Options for sustaining efforts } \\
\text { and persistence }\end{array}$ & 40 & 69 & +29 \\
\hline Options for self-regulation & 50 & 54 & +4 \\
\hline
\end{tabular}

At the end of the project, a survey was sent out to determine teachers' satisfaction with the project overall. Their feedback was positive (Table 10).

Participants indicated that they valued the content and time to plan with colleagues throughout the project. Feedback about the most meaningful learning gleaned included:

- "I think the most beneficial thing was getting to network and collaborate with other secondary science teachers."

- "The shift toward student-centered learning and using essential questions to encourage students to come up with meaningful answers is something that I feel will benefit students in the long run. This will help student learning in the long run. A better understanding of UDL Principles is also very useful as it will help with reaching all different types of learners. Understanding some of the theory that will be the foundation for the new curriculum and NGSS standards will help to develop lesson plans in advance that are in line with new learning expectations. Overall, I felt that the NGSS training will be immensely helpful, in the future."

- "There were many beneficial experiences. Learning about the Crosscutting Concepts was enlightening. However, I 
believe that the most important single factor was actually doing lessons that are NGSS. It was great to see how we could use models and improve the state of what we already teach. Since the curriculum was highlighted, I was able to plug some of the lessons right into my curriculum. This experience has changed the way I think of planning lessons and has made my lessons much more enquirybased, student-centered, and engaging. Additionally, my classroom test scores have improved."

\begin{tabular}{|c|c|c|c|c|}
\hline \multirow[t]{3}{*}{ Universal Design for Learning principle } & \multirow{2}{*}{\multicolumn{2}{|c|}{$\begin{array}{c}\text { Pre } \\
\text { Strongly } \\
\text { agree/ } \\
\text { Agree }\end{array}$}} & \multirow{2}{*}{\multicolumn{2}{|c|}{$\begin{array}{c}\text { Post } \\
\text { Strongly } \\
\text { agree/ } \\
\text { Agree }\end{array}$}} \\
\hline & & & & \\
\hline & n & $\%$ & $\mathbf{n}$ & $\%$ \\
\hline \multicolumn{5}{|l|}{$\begin{array}{l}\text { I believe it is important to provide students } \\
\text { with/offer students }\end{array}$} \\
\hline $\begin{array}{l}\text { Multiple options for engaging with the } \\
\text { content being taught }\end{array}$ & 21 & 100 & 19 & 95 \\
\hline $\begin{array}{l}\text { Opportunities for multiple representations } \\
\text { of the content being taught }\end{array}$ & 21 & 100 & 20 & 100 \\
\hline $\begin{array}{l}\text { Multiple ways to navigate the learning } \\
\text { environment and express what they know }\end{array}$ & 20 & 100 & 20 & 100 \\
\hline $\begin{array}{l}\text { Various options for perceiving the } \\
\text { information being taught }\end{array}$ & 19 & 95 & 13 & 68 \\
\hline $\begin{array}{l}\text { Options for language, mathematical } \\
\text { expressions, and symbols }\end{array}$ & 16 & 80 & 11 & 58 \\
\hline Options for comprehending the material & 20 & 100 & 18 & 90 \\
\hline Options for physical action & 19 & 95 & 20 & 100 \\
\hline $\begin{array}{l}\text { Various options for expression and } \\
\text { communication }\end{array}$ & 20 & 100 & 20 & 100 \\
\hline $\begin{array}{l}\text { Options for developing and using } \\
\text { executive functions }\end{array}$ & 14 & 78 & 18 & 90 \\
\hline Options for recruiting their interest & 17 & 94 & 20 & 100 \\
\hline $\begin{array}{l}\text { Options for sustaining effort and } \\
\text { persistence }\end{array}$ & 17 & 94 & 19 & 95 \\
\hline Options for self-regulation & 16 & 80 & 18 & 90 \\
\hline
\end{tabular}

- "The exposure to NGSS activities and experiencing useful web sites were very beneficial. Seeing teachers/leaders in action (modeling activities, etc.) showed me what to do and I saw how effective it was. Discussions with the teachers from different schools/backgrounds made for a well-rounded experience. Understanding UDL has been especially useful in class."

- "Becoming familiar with NGSS. Learning about STEAM and writing and assessment in science."

- "The week during the summer to work on lessons collaborating with peers."

- "This was an amazing experience. I would recommend it to anyone."

- "Teaching NGSS was uncomfortable at first because I needed to be sure that the kids were getting the information. It is comfortable to talk them through the concepts, but it is much more effective for the student to discover the concept. It is getting much easier since this experience. I wish I had more time to have dedicated to this experience. In my school, full lesson plans are due for everything we teach. Additionally, we are responsible for frequent PD's within our building and departments. I loved every second I was involved with this program. THANK YOU for this experience!!!!”

- "Having the whole week to work during the summer helped so much in preparing for the fall. I think that the "passion" of the leaders made a difference in our efforts, making us want to create something useful and beneficial to students. The mindset and leadership exposure should be included in future workshops."

In addition, participants were asked to rate their confidence levels around a variety of items related to teaching science before participating in the project and again at the end of their participation. Results suggest an overall increase in the teachers' confidence levels related to teaching science, especially in the area of utilizing UDL (see Table 11).

Finally, an affective checklist was administered at the end of the project. Participants indicated some sustainable changes in

Table 10: Participants' overall satisfaction with the project $(n=7)$

\begin{tabular}{|c|c|c|}
\hline Question & Strongly agree & Agree \\
\hline $\begin{array}{l}\text { The PD sessions throughout the project constituted meaningful and } \\
\text { important science for middle and high school. }\end{array}$ & 57 & 43 \\
\hline $\begin{array}{l}\text { Activities and discussions at PD sessions enhanced my knowledge and } \\
\text { understanding of related content. }\end{array}$ & 57 & 43 \\
\hline $\begin{array}{l}\text { Activities and discussions during the PD sessions I attended have } \\
\text { positively influenced my teaching of related content. }\end{array}$ & 57 & 29 \\
\hline $\begin{array}{l}\text { The information learned from participating in this project has/will } \\
\text { positively impact the achievement of my students. }\end{array}$ & 57 & 29 \\
\hline Project activities and discussions were engaging. & 57 & 43 \\
\hline $\begin{array}{l}\text { Participating in the project workshops has been a worthwhile and } \\
\text { valuable professional development experience for me. }\end{array}$ & 100 & 0 \\
\hline Item & Every day & Once a week \\
\hline $\begin{array}{l}\text { Approximately, how often do you believe you have applied the } \\
\text { information learned from the PD sessions with your students? }\end{array}$ & 29 & 57 \\
\hline
\end{tabular}


Table 11: Confidence Survey Results

\begin{tabular}{|c|c|c|}
\hline Question & Before & After \\
\hline $\mathrm{C}=$ Confident, $\mathrm{VC}=$ Very confident & $\begin{array}{c}\text { Confident/Very } \\
\text { confident (mean) }\end{array}$ & $\begin{array}{c}\text { Confident/Very } \\
\text { confident (mean) }\end{array}$ \\
\hline $\begin{array}{l}\text { Teaching the engineering design process, engineering practices, and } \\
\text { engineering habits of mind to students. }\end{array}$ & 2.4 & 3.4 \\
\hline $\begin{array}{l}\text { Allowing students/teams to "fail" and then try again in the context of an } \\
\text { engineering design challenge. }\end{array}$ & 3.3 & 4.5 \\
\hline Teaching scientific content and practices to students. & 3.2 & 4.3 \\
\hline $\begin{array}{l}\text { Teaching students outside, where the outdoor environment is central to } \\
\text { the lesson. }\end{array}$ & 3 & 3.9 \\
\hline Provide opportunities for students to develop and use models. & 2.8 & 4.4 \\
\hline Engaging students in planning and carrying out investigations. & 2.8 & 4.3 \\
\hline Integrating Universal Design for Learning into lesson planning. & 2.8 & 4.3 \\
\hline $\begin{array}{l}\text { Engaging students in writing arguments focused on discipline-specific } \\
\text { content. }\end{array}$ & 2.8 & 4 \\
\hline
\end{tabular}

behavior. Table 12 shows the percentage of participants who answered yes or no to each item.

\section{DISCUSSION AND CONCLUSION}

Implementation of the NGSS requires a significant shift in how teachers plan for and implement instruction in the classroom. In addition, the inclusion of diverse learners in general education settings further intensifies the need for all teachers to have the necessary skills to plan in ways that meet those students' needs as well. Effective implementation of the new NGSS requires that general and special educators collaborate to ensure meaningful access for students with disabilities. Findings suggest that this professional development program was successful and can serve as a model for providing teachers with the required content and pedagogical knowledge as well as the opportunity and skills to engage in such critical collaborations. It is important to note, however, that the small sample size is a weakness of the study and may limit the generalizability of the findings.

One area that was consistently identified by teachers as critical to the effective implementation of the NGSS was the ability to collaborate and plan with others. The collaboration was deemed important not only within grade-level teams but was also important across grade levels as well as with special educators. Teachers benefitted from this collaborative planning and felt it enhanced their work as well as their students' learning outcomes. Results of this study support the position that professional development programs should offer teachers time and space to work and plan collaboratively.

Participating teachers identified hands-on experiences and examples as helpful components of the NGSS professional development sessions. During the spring professional development sessions, the NGSS practices were presented using actual labs and activities. Being able to approach the work from the viewpoint of their students helped teachers develop a deeper understanding of the content and subsequently develop more effective lesson plans. It also
Table 12: Result of affective checklist

\begin{tabular}{lcc}
\hline Behavior & Yes (\%) & No (\%) \\
\hline $\begin{array}{l}\text { Read an article in a newspaper or magazine about a } \\
\text { science content issue. }\end{array}$ & 100 & 0 \\
$\begin{array}{l}\text { Asked students to share a science topic or issue they } \\
\text { want to know more about. }\end{array}$ & 90 & 10 \\
$\begin{array}{l}\text { Found myself more interested in and/exploring how } \\
\text { I could make better data-driven decisions about } \\
\text { classroom instruction. }\end{array}$ & 40 & 60 \\
$\begin{array}{l}\text { Used a new technology tool (game, video clip or } \\
\text { website) on a science topic in my classroom. }\end{array}$ & 100 & 0 \\
$\begin{array}{l}\text { Coplanned a science lesson with a colleague. } \\
\text { Talked to a fellow teacher about something you }\end{array}$ & 100 & 0 \\
learned in the program. & 100 & 0 \\
$\begin{array}{l}\text { Found myself checking out NGSS as I planned a } \\
\text { new science classroom activity. }\end{array}$ & 90 & 10 \\
$\begin{array}{l}\text { Talked with a colleague about how helpful I found it } \\
\text { is to link science ideas and NGSS practices. }\end{array}$ & 80 & 20 \\
$\begin{array}{l}\text { Sent home a note to families about the exciting } \\
\text { science or math activities going on in class. }\end{array}$ & 60 & 40 \\
$\begin{array}{l}\text { Planned/carried out a science/NGSS focused activity } \\
\text { linked to MD Standards with my students. }\end{array}$ & 100 & 0 \\
$\begin{array}{l}\text { I feel more confident about including UDL } \\
\text { components in planning my lessons. }\end{array}$ & 100 & 0 \\
\hline
\end{tabular}

provided them with exemplar models they could use in their own classrooms.

A final area identified as important by teachers was the use of the UDL framework throughout the professional development. Overall, content coaches observed an increase in the application of the UDL principles in planning. In addition, participants selfrated that they had greater confidence in applying UDL and that it was beneficial for students.

Ultimately, the overarching goal of this project was to improve student-learning outcomes by providing teachers with quality, sustained professional development on the NGSS practices, crosscutting concepts, integrating the Common Core ELA standards, and applying UDL. During the focus group interviews, several participants provided specific examples 
illustrating how what they learned positively impacted their students' achievement. In addition, feedback from the spring professional development sessions, summer workshop, and final project survey, participants consistently reported that their participation in the project has had a positive impact on the achievement of their students.

\section{REFERENCES}

Anderson, R.D. (2002). Reforming science teaching: What research says about inquiry. Journal of Science Teacher Education, 13(1), 1-12.

Darling-Hammond, L., Wei, R.C., Andree, A., Richardson, N., \& Orphanos, S. (2009). Professional Learning in the Learning Profession: A Status Report on Teacher Development in the United States and Abroad. Dallas, TX: National Staff Development Council.

Davis, E.A., \& Krajcik, J. (2005). Designing educative curriculum materials to promote teacher learning. Educational Researcher, 34(3), 3-14.

Furtak, E.M., Ruiz-Primo, M.A., Shemwell, J.T., Ayala, C.C., Brandon, P.R., Shavelson, R.J., \& Yin, Y. (2008). On the fidelity of implementing embedded formative assessments and its relation to student learning. Applied Measurement in Education, 21(4), 360-389.

Graham, S., \& Hebert, M. (2011). Writing to read: A meta-analysis of the impact of writing and writing instruction on reading. Harvard Educational Review, 81(4), 710-744.

Gunel, M., Hand, B., \& Prain, V. (2007). Writing for learning in science: A secondary analysis of six studies. International Journal of Science and Mathematics Education, 5(4), 615-637.

Guskey, T. (2002). Professional development and teacher change. Teachers and Teaching: Theory and Practice, 8(3-4), 382-391.

Hickey, D.T., Kindfield, A.C.H., Horwitz, P., \& Christie, M. (2003). Assessment-oriented scaffolding of student and teacher performance in a technology-supported genetics environment. American Educational Research Journal, 40(2), 495-538.

Jonassen, D.H. (1994). Thinking technology: Toward a constructivist design model. Educational Technology, 34(3), 34-37.

Kim, J.S. (2005). The effects of a constructivist teaching approach on student academic achievement, self-concept, and learning strategies. Asia Pacific Education Review, 6(1), 7-19.

Lorsbach, A., \& Tobin, K. (2009). Constructivism as a Referent for Science Teaching. Research Matters to the Science Teacher. Available from: https://www.narst.org/publications/research/constructivism.cfm. [Last accessed on 2019 May 18].

Mason, L., \& Boscolo, P. (2000). Writing and conceptual change: What changes? Instructional Science, 28, 199-226.

Meyer, D.L. (2009). The poverty of constructivism. Educational Philosophy and Theory, 41(3), 332-341.

Moje, E.B. (2008). Reading the Adolescent Reader: Profiles of Reader Identities, Knowledge, Strategy, and Skill. Atlanta, GA: Paper Presented at the Annual Convention of the International Reading Association.

National Research Council. (1996). National Science Education Standards. Washington, DC: The National Academies Press.

Prain, V., \& Hand, B. (1996). Writing for learning in secondary science: Rethinking practices. Teaching and Teacher Education, 12(6), 609-626.

Pugach, M.C., \& Johnson, L.J. (2002). Collaborative Practitioners, Collaborative Schools. $2^{\text {nd }}$ ed. Denver: Love Publishing.

Reiser, B.J. (2013). What Professional Development Strategies are needed for Successful Implementation of the Next Generation Science Standards? K-12 Center at ETS. Available from: https://www.ets.org/ Media/Research/pdf/reiser.pdf. [Last accessed on 2019 May 18].

Rose, D.H., Meyer, A., Strangman, N., \& Rappolt, G. (2002). Teaching Every Student in the Digital Age: Universal Design for Learning. Alexandria, VA: Association for Supervision and Curriculum Development.

Shanahan, C., \& Shanahan, T. (2008). Teaching disciplinary literacy to adolescents: Rethinking content-area literacy. Harvard Educational Review, 78(1), 40-59.

Shanahan, C., Shanahan, T., \& Misischia, C. (2012). Analysis of expert readers in three disciplines: History, mathematics, and chemistry. Journal of Literacy Research, 43(4), 393-429.

Statewide Task Force to Explore the Incorporation of Universal Design for Learning UDL Principles into Maryland's Education Systems (Statewide Task Force). (2011). A Route for Every Learner: Universal Design for Learning (UDL) as a Framework for Supporting Learning and Improving Achievement for All Learners in Maryland, Prekindergarten Through Higher Education. Available from: http:// marylandpublicschools.org/about/Documents/OCP/SpecialReports/ ARouteforEveryLearnerReport032511.pdf. [Last retrieved on 2019 May 15].

United States Department of Education. (2008). Higher Education Opportunity Act (HEOA) of 2008. Public Law 110-315, 20 U.S.C. Available from: https://www2.ed.gov/policy/highered/leg/hea08/index. html. [Last retrieved on 2019 Jun 7].

Wallace, C.S., Hand, B., \& Prain, V. (2004). Writing and Learning in the Science Classroom. Boston: Kluwer. 